\title{
PENGARUH STRATEGI PEMBELAJARAN DAN MOTIVASI BELAJAR TERHADAP HASIL BELAJAR PENDIDIKAN AGAMA ISLAM SISWA SEKOLAH DASAR NEGERI 1 BIREM KABUPATEN ACEH TIMUR
}

\author{
Husniah \\ Penulis adalah Guru Sekolah Dasar Negeri 1 Birem Kabupaten Aceh Timur
}

\begin{abstract}
The objectives of this research were to find out: (1) the different effect between inductive and deductive instructional strategy toward Islamic Education achievement, (2) the difference of the Islamic Education achievement between student with high learning motivation and low learning motivation, and (3) the interaction between instructional strategy and learning motivation toward Islamic Education achievement. The population of this research was all students of Grade V V SDN 1 Birem consisting of two classes. The sampling technique applied was cluster random sampling taught with inductive instructional strategy and the students taught with deductive instructional strategy. The instrument used to measure the Islamic Education achievement was a multiple choice test. The instrument used to measure the students' learning motivation was questionnaire. The normality test used Liliefors and the homogeneity test was Fisher test and Bartlett test. The data analysis technique was Analysis of Variance with two-way at the level of significance $\alpha=0,05$ followed by Scheffe test. The research findings were: (1) on average the students' Islamic Education achievement taught with inductive instructional strategy was $\bar{X}=28.14$ which was higher than the average the students' Islamic Education achievement taught with deductive instructional strategy, which was $\bar{X}=27.07$ with $\mathrm{F}_{\text {count }}=35.08$ $>\mathrm{F}_{\text {table }}=3.96$, (2) on average the student' Islamic Education achievement with high learning motivatione was $\bar{X}=29.91$, which was higher than the student' Islamic Education achievement with low learning motivation was $\bar{X}=26.05$ with $\mathrm{F}_{\text {count }}=4.28$ $>\mathrm{F}_{\text {table }}=3.96$, and (3) there was an interaction between instructional strategy and learning motivation toward Islamic Education achievement with $F$ count $=9,94>\mathrm{F}$ table $=3.96$.
\end{abstract}

Kata kunci: Stategi Belajar, Motivasi Belajar, Hasil Belajar PAI

\section{PENDAHULUAN}

Guru sebagai seorang desainer dalam pembelajaran berperan dalam menentukan berhasil tidaknya pencapaian tujuan pembelajaran. Agar tujuan pembelajaran dapat tercapai guru dituntut untuk memiliki keterampilan dan dapat mengorganisasikan bahan sedemikian rupa sehingga bahan pelajaran menjadi menarik. Namun saat ini terdapat kecenderungan bahwa guru sering menggunakan strategi pembelajaran monoton yang kurang interaktif serta tidak bervariasi, hingga 
mengakibatkan kebosanan siswa dan mengurangi minat siswa dalam mempelajari PAI, hal ini berdampak pada perolehan nilai siswa yang belum maksimal.

Data awal yang berhasil diperoleh melalui wawancara awal terhadap guru pengampu matapelajaran Pendidikan Agama Islam SDN 1 Birem Aceh Timur pada tanggal 11 November 2017 dapat disimpulkan bahwa sebagian besar guru berkesulitan dalam menemukan cara untuk mengubah asumsi sebagian besar siswa yang beranggapan bahwa mata pelajaran Pendidikan Agama Islam merupakan mata pelajaran yang menekankan kepada pembentukan pengetahuan, sikap dan keterampilan terutama dalam menjalani kehidupan beragama kesehariannya. Hal ini lebih dirasakan oleh siswa yang kurang memiliki kemampuan awal dalam pembelajaran Pendidikan Agama Islam serta kurang tinggi motivasi belajarnya.

Kemampuan awal dan motivasi belajar siswa yang berbeda tentulah memerlukan perlakuan yang berbeda dalam proses pembelajarannya. Penggunaan strategi pembelajaran yang monoton tanpa inovasi serta kurang bervariasi yang diterapkan guru tidaklah mampu memberikan hasil yang signifikan dalam pencapaian kompetensi siswa.

Ketidaktepatan dalam penggunaan metode atau strategi pembelajaran akan menimbulkan kejenuhan bagi siswa dalam menerima materi yang disampaikan sehingga materi kurang dapat dipahami yang akan mengakibatkan siswa menjadi apatis. Oleh karena itu guru tidak hanya dituntut memiliki pengetahuan dan kemampuan mengajar, tetapi juga mewujudkan kompleksitas peran sesuai dengan tugas dan fungsi yang diembannya secara kreatif (Agung, 2010:23).

Untuk itu peranan guru sebagai desainer pembelajaran tidak dapat diabaikan baik dalam hal memilih strategi maupun media pembelajaran yang sesuai untuk para siswanya. Hal ini diungkapkan mengingat pentingnya peranan guru dalam menentukan pencapaian tujuan pembelajaran yang pada akhirnya dapat meningkatkan hasil belajar Pendidikan Agama Islam siswa SDN 1 Birem.

\section{KAJIAN TEORI}

Winkel (2009:59) menyebutkan bahwa belajar adalah suatu aktivitas mental/psikis yang berlangsung dalam interaksi aktif dengan lingkungan, yang menghasilkan sejumlah perubahan-perubahan dalam pengetahuan, pemahaman, keterampilan, nilai, serta sikap. Sedangkan Slameto (2003:2) berpendapat belajar ialah 
proses usaha yang dilakukan seseorang untuk memperoleh suatu perubahan tingkah laku yang baru secara keseluruhan, sebagai hasil pengalamannya sendiri dalam interaksi dengan lingkungannya.

Syah (2010:88) mengutip Caplin menjelaskan definisi belajar yakni: (1) belajar adalah perolehan perubahan tingkah laku yang relatif menetap sebagai akibat latihan dan pengalaman, dan (2) belajar adalah proses memperoleh respon-respon sebagai akibat adanya latihan khusus. Selanjutnya Hamalik (2004:27) menyebutkan bahwa belajar adalah modifikasi atau memperteguh kelakuan melalui pengalaman.

Sudjana (2005:22) menjelaskan hasil belajar adalah kemampuan yang dimiliki siswa setelah ia menerima pelajaran. Hal senada dijelaskan Nurmawati (2016:53) bahwa hasil belajar merupaka segala prilaku yang dimiliki peserta didik sebagai akibat dari proses belajar yang ditempuhnya.

Dimyati dan Mudjiono (2006:10) menjelaskan bahwa belajar merupakan kegiatan yang kompleks, dengan hasil belajarnya berupa kapabilitas. Setelah belajar seseorang akan memiliki keterampilan, pengetahuan, sikap dan nilai sebagai akibat dari pengalaman. Hal ini mengandung makna bahwa belajar menyangkut perubahan dalam perilaku dan keterampilan manusia yang dapat dipakai.

Definisi belajar merujuk kepada paparan di atas maka dapatlah disimpulkan bahwa belajar merupakan suatu proses perubahan tingkah laku yang bersifat permanen sebagai akibat latihan dan pengalaman, berupa aktivitas mental yang berlangsung secara bertahap dan terarah dalam interaksi aktif dengan lingkungan.

Hasil belajar menurut Romiszowski (1981:242) adalah perolehan hasil dalam bentuk pengetahuan dan keterampilan. Hasil belajar yang didefinisikan tersebut berupa keluaran (output) dari suatu sistem pemerosesan masukan (input) di mana masukan dari sistem tersebut berupa bermacam-macam informasi sedangkan keluarannya adalah perbuatan atau kinerja (performance).

Bloom dalam Sudijono (2008:49) menyatakan bahwa hasil belajar dapat dikatagorikan dalam tiga ranah, yakni:

a. Ranah kognitif meliputi tujuan pendidikan yang berkenaan dengan ingatan atau pengenalan terhadap pengetahuan dan pengembangan kemampuan intelektual dan keterampilan berpikir yang terbagi menjadi enam jenjang, yaitu: (1) pengetahuan (knowledge), (2) pemahaman (comprehension), (3) penerapan 
(application), (4) analisis (analysis), (5) sistesis (synthesis), dan (6) penilaian (evaluation).

b. Ranah afektif berkenaan dengan minat, sikap dan nilai serta pengembangan penghargaan dan penyesuaian diri yang terbagi lima jenjang, yakni: (1) penerimaan (receiving), (2) menanggapi (responding), (3) menilai (valuing), (4) mengorganisasikan (organization), dan (5) karakterisasi (characterization).

c. Ranah psikomotorik yaitu: (1) persepsi, (2) kesiapan, (3) gerakan terbimbing, (4) gerakan terbiasa, (5) gerakan kompleks, (6) penyesuaian pola gerakan, dan (7) kreativitas.

Hasil belajar Pendidikan Agama Islam di sekolah umum dijelaskan bahwa Pendidikan Agama Islam adalah usaha sadar untuk menyiapkan siswa dalam menyakini, memahami, menghayati dan mengamalkan agama Islam melalui kegiatan bimbingan, pengajaran dan atau latihan dengan memperlihatkan tuntunan untuk menghormati agama lain dalam hubungan kerukunan antar umat beragama dalam masyarakat untuk mewujudkan persatuan nasional. (Muhaimin, 2001:75).

Strategi pembelajaran induktif berpedoman pada urutan kegiatan yang bergerak dari hal yang bersifat khusus kepada yang umum. Menurut Suparman (2012:261) strategi pembelajaran induktif dimulai dengan pemberian berbagai kasus, fakta, contoh, atau sebab yang mencerminkan suatu konsep atau prinsip, kemudian peserta didik dibimbing untuk berusaha keras mensistensi, menemukan, atau menyimpulkan prinsip dasar dari pelajaran tersebut.

Suparman (2012:261) menjelaskan bahwa strategi pembelajaran induktif tepat digunakan dalam kegiatan pembelajaran apabila: (1) peserta didik telah mengenal atau telah mempunyai pengalaman yang berhubungan dengan mata pelajaran tersebut, (2) materi yang akan diajarkan berupa keterampilan komunikasi antara pribadi, sikap, pemecahan masalah dan pengambilan keputusan, (3) tenaga pengajar mempunyai keterampilan mendengarkan yang baik, fleksibel, terampil mengajukan pertanyaan, terampil mengulang pernyataan dan sabar, dan (4) waktu yang tersedia cukup panjang.

Joyce, Weil dan Calhoun (2009:115) menjelaskan pembelajaran induktif dirancang untuk melatih siswa membuat konsep dan sekaligus untuk mengajarkan konsep-konsep dan cara penerapannya pada siswa. Strategi pembelajaran ini juga mengajar minat siswa pada logika, minat pada bahasa dan arti kata-kata dan minat pada sifat pengetahuan. 
Strategi pembelajaran deduktif berpedoman pada urutan kegiatan yang bergerak dari hal yang bersifat umum kepada yang khusus. Suparman (2012:260) menyatakan strategi pembelajaran deduktif mulai dengan pemberian penjelasan tentang prinsip-prinsip isi pelajaran, kemudian disusul dengan penerapan atau contohcontohnya pada situasi tertentu. Dengan kata lain strategi pembelajaran deduktif membelajarkan siswa secara langsung melalui strategi yang berangkat dari hal-hal umum menuju sesuatu yang khusus.

Suparman (2012:260) menjelaskan bahwa strategi pembelajaran deduktif tepat digunakan dalam kegiatan pembelajaran apabila: (1) peserta didik belum mengenal pengetahuan yang sedang dipelajari, (2) isi pelajaran meliputi terminologi, teknis dan bidang yang kurang membutuhkan proses berpikir kritis, (3) pengajar mempunyai persiapan yang baik dan pembicara yang baik, dan (4) waktu yang tersedia singkat.

Sudjana dan Suwariyah (1991:82) menyatakan bahwa strategi pembelajaran deduktif adalah pembelajaran yang dikembangkan berdasarkan cara berpikir menarik kesimpulan dari pernyataan umum menjadi pernyataan khusus, artinya dari konsep teori menuju fakta. Pada pelaksanaannya dimulai dari pengenalan teori, konsep, atau prinsip yang terdapat dalam bidang studi kemudian dilanjutkan dengan pengujian, pembuktian atau penggunaan melalui kegiatan di dalam atau di luar kelas.

Sardiman (2010:38) menyatakan motivasi belajar merupakan faktor psikis yang bersifat non intelektual. Maksudnya bahwa motivasi belajar memiliki peranan yang khas dalam menumbuhkan semangat untuk belajar dimana siswa yang memiliki motivasi yang kuat akan mempunyai banyak energi untuk melakukan kegiatan belajar. Motivasi juga berarti daya penggerak di dalam diri orang yang melakukan aktivitasaktivitas tertentu demi mencapai suatu tujuan tertentu (Winkel, 2009:173).

\section{METODE PENELITIAN}

Penelitian ini menggunakan metode penelitian eksperimental semu (quasi eksperimental research). Hal ini dikarenakan subjek penelitian tidak dapat dikendalikan secara penuh, seperti penelitian yang dilakukan di dalam kelas. Rancangan penelitian menggunakan desain faktorial 2 x 2. Populasi dalam penelitian adalah seluruh siswa kelas V (lima) SDN 1 Birem tahun pelajaran 2017/2018 yang terdiri dari 2 (dua) kelas dengan sebaran jumlah siswa 40 orang per kelas. Dari ketiga kelompok kelas yang menjadi populasi, diambil secara acak melalui undian, dua 
kelompok kelas sebagai sampel penelitian. terpilih kelas V-2, untuk kertas yang tidak di cabut maka ditetapkan sebagai kelas dengan strategi pembelajaran deduktif, dalam hal ini terpilih kelas V-1.

\section{TEMUAN DAN PEMBAHASAN PENELITIAN}

Hipotesis pertama yang menyatakan hasil belajar Pendidikan Agama Islam siswa SDN 1 Birem Kabupaten Aceh Timur yang dibelajarkan dengan strategi pembelajaran induktif lebih tinggi dibandingkan dengan siswa SDN 1 Birem Kabupaten Aceh Timur yang dibelajarkan dengan strategi pembelajaran deduktif.

Hal ini terlihat dari rata-rata hasil belajar Pendidikan Agama Islam siswa SDN 1 Birem Kabupaten Aceh Timur yang dibelajarkan dengan strategi pembelajaran induktif $(\bar{X}=28,14)$ lebih tinggi daripada rata-rata hasil belajar Pendidikan Agama Islam siswa SDN 1 Birem Kabupaten Aceh Timur yang dibelajarkan dengan strategi pembelajaran deduktif $(\bar{X}=27,07)$.

Temuan penelitian ini menunjukkan bahwa strategi pembelajaran induktif terbukti efektif untuk meningkatkan hasil belajar Pendidikan Agama Islam siswa SDN 1 Birem Kabupaten Aceh Timur, baik untuk kelompok siswa dengan motivasi belajar tinggi maupun siswa dengan motivasi belajar rendah. Dengan kata lain temuan ini menunjukkan bahwa untuk mengajarkan materi Pendidikan Agama Islam lebih baik menggunakan strategi pembelajaran induktif daripada dengan strategi pembelajaran deduktif.

Pengujian hipotesis kedua menunjukkan bahwa siswa SDN 1 Birem Kabupaten Aceh Timur yang memiliki motivasi belajar tinggi memperoleh hasil belajar Pendidikan Agama Islam lebih tinggi dari pada siswa yang memiliki motivasi belajar rendah. Hal ini membuktikan bahwa motivasi belajar signifikan untuk membedakan hasil belajar Pendidikan Agama Islam. Motivasi belajar dalam penelitian ini dikategorikan atas dua kategori yaitu tinggi dan rendah.

Hasil analisis data secara keseluruhan diperoleh rata-rata hasil belajar Pendidikan Agama Islam siswa SDN 1 Birem Kabupaten Aceh Timur dengan motivasi belajar tinggi lebih tinggi daripada hasil belajar Pendidikan Agama Islam siswa dengan motivasi belajar rendah. Hal ini menunjukkan bahwa siswa yang memiliki motivasi belajar tinggi secara rata-rata mempunyai hasil belajar Pendidikan Agama Islam lebih tinggi dibandingkan dengan siswa dengan motivasi belajar rendah. Dengan demikian 
siswa dengan motivasi belajar tinggi lebih memahami dan menguasai materi ajar atau keterampilan berbahasa yang dibelajarkan dibandingkan siswa yang memiliki motivasi belajar rendah.

Temuan ini menunjukkan bahwa keberhasilan suatu pembelajaran ditentukan oleh berbagai faktor, diantaranya adalah faktor yang berhubungan dengan siswa dan dalam hal ini adalah motivasi belajar siswa. Motivasi belajar adalah salah satu faktor yang berperan dalam mendorong siswa melakukan aktivitas belajar. Sebagai daya penggerak dalam diri seseorang untuk memperoleh keberhasilan dalam proses pembelajaran maka dapat dibedakan siswa yang memiliki motivasi belajar rendah dan motivasi belajar tinggi.

Siswa yang bermotivasi belajar tinggi pasti terlihat berbeda jika dibandingkan dengan yang bermotivasi rendah. Demikian pula halnya dalam mengikuti pembelajaran Pendidikan Agama Islam, siswa memiliki motivasi belajar yang berbeda-beda antara siswa yang satu akan berbeda dengan siswa yang lain. Siswa yang memiliki motivasi belajar yang tinggi akan lebih termotivasi untuk belajar, mengolah informasi atau pengetahuan dan mengemukkaan ide dan pemikiran yang ada dibenaknya bila dibandingkan dengan siswa yang memiliki motivasi rendah.

Siswa yang memiliki motivasi belajar yang tinggi dapat belajar dengan penuh perhatian dan berusaha memperoleh hasil belajar yang terbaik dan biasanya akan mencapai hasil belajar sesuai kemampuannya. Mereka senantiasa memiliki semangat belajar yang tinggi, dan cenderung ingin mencari pengetahuan baru. Mereka juga cenderung lebih percaya diri dalam mengejar keberhasilan dalam belajar.

Siswa yang bermotivasi belajar tinggi selalu dapat menyelesaikan tugas yang diberikan dengan mudah, dan jika mengalami kesulitan, mereka akan bertanya dan optimis dapat menyelesaikan masalah dengan baik. Mereka biasanya memiliki pikiran yang positif, kreatif, dan aktif dalam mencari pengetahuan yang diinginkannya. Oleh sebab itu, mereka selalu puas dengan hasil yang dicapainya karena hasilnya senantiasa sesuai dengan tujuan yang diharapkannya.

Sebaliknya, siswa yang memiliki motivasi belajar yang rendah tidak memberi perhatian maksimal terhadap apa yang mereka pelajari. Mereka cenderung kurang bersemangat mencari pengetahuan baru. Secara umum, mereka memiliki kepercayaan diri yang rendah sebab mereka tidak pernah yakin pada kemampuannya. Siswa yang bermotivasi belajar rendah cepat menyerah jika mengalami kesulitan dalam belajar, 
yang pada akhirnya mengakibatkan kurang baiknya hasil yang didapat dalam pembelajaran. Mereka mudah putus asa dan bersikap pasif hingga mengakibatkan prestasi belajarnya tertinggal dari siswa lainnya.

Pengujian hipotesis ketiga terdapat interaksi antara strategi pembelajaran dan motivasi belajar terhadap hasil belajar Pendidikan Agama Islam siswa SDN 1 Birem Kabupaten Aceh Timur. Apabila dilihat rata-rata hasil belajar Pendidikan Agama Islam pada kelompok siswa dengan motivasi belajar tinggi yang dibelajarkan dengan strategi pembelajaran induktif lebih tinggi dibandingkan dengan rata-rata hasil belajar Pendidikan Agama Islam siswa yang dibelajarkan dengan strategi pembelajaran deduktif.

Rata-rata hasil belajar Pendidikan Agama Islam siswa SDN 1 Birem Kabupaten Aceh Timur dengan motivasi belajar rendah yang dibelajarkan dengan strategi pembelajaran induktif lebih rendah dibandingkan dengan rata-rata hasil belajar Pendidikan Agama Islam siswa SDN 1 Birem Kabupaten Aceh Timur dengan motivasi belajar rendah yang dibelajarkan dengan strategi pembelajaran deduktif. Hal ini berarti bahwa bagi kelompok siswa dengan motivasi belajar rendah lebih baik menggunakan strategi pembelajaran deduktif dibandingkan d`engan menggunakan strategi pembelajaran induktif. Dengan demikian dapat ditarik kesimpulan bahwa strategi pembelajaran dan motivasi belajar signifikan mempengaruhi hasil belajar Pendidikan Agama Islam siswa SDN 1 Birem Kabupaten Aceh Timur.

Jika diperhatikan lebih lanjut bahwa dalam strategi pembelajaran induktif rata-rata hasil belajar Pendidikan Agama Islam siswa SDN 1 Birem Kabupaten Aceh Timur dengan motivasi belajar tinggi $(\bar{X}=32,36)$ lebih tinggi daripada hasil belajar Pendidikan Agama Islam siswa dengan motivasi belajar rendah $(\bar{X}=25,68)$.

Pada strategi pembelajaran deduktif, rata-rata hasil belajar Pendidikan Agama Islam siswa SDN 1 Birem Kabupaten Aceh Timur dengan motivasi belajar tinggi $(\bar{X}=$ 28,20) lebih tinggi daripada hasil belajar Pendidikan Agama Islam siswa SDN 1 Birem Kabupaten Aceh Timur dengan motivasi belajar rendah $(\bar{X}=26,24)$. Hal ini menunjukkan bahwa strategi pembelajaran dan motivasi belajar signifikan untuk membedakan hasil belajar Pendidikan Agama Islam siswa, di mana hasil belajar Pendidikan Agama Islam siswa dengan motivasi belajar tinggi baik yang dibelajarkan 
dengan strategi pembelajaran induktif, sedangkan bagi siswa dengan motivasi belajar rendah lebih baik dibelajarkan dengan strategi pembelajaran deduktif.

Temuan penelitian ini menjelaskan bahwa strategi pembelajaran induktif merupakan strategi pembelajaran yang berupaya membangkitkan rasa ingin tahu siswa melalui mengamati media yang disajikan dan bacaan yang diberikan. Siswa yang memiliki motivasi belajar tinggi lebih sesuai diberikan strategi pembelajaran induktif ini karena perhatian dan semangat belajarnya yang tinggi memungkinkan mereka untuk menggali sendiri pengetahuan baru yang terdapat pada materi dan mereka dapat berkonsentrasi serta berperan aktif dalam kegiatan belajar. Dengan strategi pembelajaran induktif, siswa yang bermotivasi tinggi akan merasa senang karena mereka tertantang untuk mendapatkan pengetahuan baru dalam pembelajaran, dan ini membuat mereka dapat meningkatkan hasil belajarnya.

Siswa yang memiliki motivasi belajar rendah kurang tepat dibelajarkan dengan strategi pembelajaran induktif, karena mereka akan putus asa jika tidak mampu menemukan pengetahuan baru. Siswa yang bermotivasi rendah tidak menginginkan kegiatan yang menantang, mereka lebih tertarik mendapatkan pengetahuan baru dari guru, bukan dengan menemukan sendiri. Peserta didik cenderung pasif dan tidak ingin berprestasi sehingga membuat hasil belajar menjadi rendah.

Strategi pembelajaran deduktif adalah strategi penyampaian pembelajaran yang diwali dengan kegiatan membaca materi dan mendengarkan uraian dari guru. Strategi pembelajaran ini tidak menuntut keaktifan siswa, melainkan gurulah yang lebih berperan. Siswa yang memiliki motivasi belajar tinggi akan kurang antusias dengan strategi pembelajaran deduktif ini karena kegiatannya yang tidak menantang serta terkesan monoton sehingga akhirnya mereka menjadi tidak konsentrasi. Hal ini akan membuat perolehan hasil belajarnya juga menjadi rendah.

Sebaliknya, siswa yang memiliki motivasi belajar rendah akan merasa tertarik dengan strategi pembelajaran deduktif ini karena mereka tidak dituntut untuk menemukan sendiri pengetahuan baru pada materi yang disampaikan. Mereka telah diberikan bacaan dan uraian penjelasan oleh guru, sehingga mereka merasa tidak kesulitan dalam mengkonstruksi pengetahuan baru. Hal ini mengakibatkan timbulnya minat mereka dan pada akhirnya memberikan hasil belajar yang baik dalam pembelajaran. 


\section{SIMPULAN DAN REKOMENDASI}

Simpulan yang dapat ditarik dalam temuan penelitian ini adalah sebagai berikut:

1. Rata-rata hasil belajar Pendidikan Agama Islam siswa SDN 1 Birem Kabupaten Aceh Timur yang dibelajarkan dengan strategi pembelajaran induktif ( $\bar{X}=$ $28,14)$ lebih tinggi dibandingkan dengan rata-rata hasil belajar Pendidikan Agama Islam siswa SDN 1 Birem Kabupaten Aceh Timur yang dibelajarkan dengan strategi pembelajaran deduktif $(\bar{X}=27,07)$. Hal ini juga dibuktikan dengan harga $\mathrm{F}_{\text {hitung }} 35,08>\mathrm{F}_{\text {tabel }}$ 3,96.

2. Rata-rata hasil belajar Pendidikan Agama Islam siswa SDN 1 Birem Kabupaten Aceh Timur dengan motivasi belajar tinggi $(\bar{X}=29,91)$ secara keseluruhan baik yang dibelajarkan dengan strategi pembelajaran induktif maupun strategi pembelajaran deduktif lebih tinggi dibandingkan dengan rata-rata hasil belajar Pendidikan Agama Islam siswa SDN 1 Birem Kabupaten Aceh Timur dengan motivasi belajar rendah $(\bar{X}=26,05)$. Hal ini juga dibuktikan dengan harga $\mathrm{F}_{\text {hitung }} 4,28>\mathrm{F}_{\text {tabel }} 3,96$.

3. Terdapat interaksi antara strategi pembelajaran dan motivasi belajar siswa yang memberikan perbedaan pengaruh terhadap hasil belajar Pendidikan Agama Islam siswa SDN 1 Birem Kabupaten Aceh Timur. Hal ini terbukti dengan harga $\mathrm{F}_{\text {hitung }} 9,94>\mathrm{F}_{\text {tabel }}$ 3,96.

Berdasakan hasil temuan-temuan penelitian sebelumnya maka dapatlah disampaikan beberapa saran sebagai berikut:

1. Strategi pembelajaran induktif memberikan hasil belajar yang lebih tinggi dalam mata pelajaran Pendidikan Agama Islam dibandingkan dengan strategi pembelajaran deduktif. Oleh karena itu bagi guru disarankan dalam kegiatan pembelajaran perlu menerapkan strategi pembelajaran induktif.

2. Bagi siswa dengan motivasi belajar tinggi disarankan untuk menggunakan strategi pembelajaran induktif, sedangkan bagi siswa dengan motivasi belajar rendah disarankan menggunakan strategi pembelajaran deduktif.

3. Karakteristik siswa yang diteliti dari penelitian ini hanya terbatas kepada motivasi belajar. Untuk itu kepada peneliti lain disarankan untuk meneliti karakteristik siswa yang lain misalnya retensi, gaya kognitif dan yang lainnya. 
4. Strategi pembelajaran induktif dan deduktif ini hanya diterapkan pada mata pelajaran Pendidikan Agama Islam dalam ranah kognitif, disarankan untuk peneliti lain dapat meneliti dalam ranah yang lainnya.

\section{DAFTAR PUSTAKA}

Dimyati dan Mudjiono. Belajar dan Pembelajaran. Jakarta: Rineka Cipta, 2006.

Hamalik, Oemar. Proses Belajar Mengajar. Jakarta: Bumi Aksara, 2004

Joyce, B.,Weil, M. \& Calhoun, E. Models of Teaching, Model-Model Pengajaran. Alih Bahasa: Achmad Fawaid dan Ateila Mirza, Yogyakarta: Pustaka Pelajar, 2009.

Sardiman. Motivasi Belajar Mengajar. Jakarta: Raja Grafindo Persada, 2010.

Slameto. Belajar dan Faktor-Faktor yang Mempengaruhinya. Jakarta: Rineka cipta, 2003.

Sudjana, Nana. Penilaian Hasil Proses Belajar Mengajar. Bandung: Remaja Rosdakarya, 2005.

Sudjana, Nana dan Suwariyah, Wari. Model-Model Mengajar CBSA. Bandung: Sinar Baru Bandung, 1991

Suparman, M. Atwi. Desain Instruksional Modern. Panduan Para Penajar Dan Inovator Pendidikan. Jakarta: Erlangga, 2012.

Syah, Muhibbin. Psikologi Pendidikan Dengan Pendekatan Baru. Bandung: Remaja Rosdakarya, 2010.

Winkel, W.S. Psikologi Pengajaran. Yogyakarta: Media Abadi, 2009 